\title{
DEMOCRATIC PARENTING IN DEVELOPING EMOTIONAL INTELLIGENCE AND YOUTH RELIGIOSITY IN KRAMATAGUNG PROBOLINGGO
}

\author{
Nur Khosiah ${ }^{1)}$, Agustiarini Eka Dheasari $^{2)}$, Zainal Abidin ${ }^{3)}$ \\ ${ }^{1,2,3)}$ STAI Muhammadiyah Probolinggo \\ e-mail: nurkhosiah944@gmail.com ${ }^{1}$, agustiarinieka@ @mail.com $^{2)}$, \\ kopral_zainal@yahoo.com ${ }^{3)}$
}

\begin{abstract}
Education for children starts from family because it will determine the character of children in adolescence. The purpose of this study is to determine the role of democratic parenting in building emotional intelligence and religiosity in adolescents. Because without parental guidance the child will experience deviations in the daily behavior. The research subject was in Kramatagung Village, Bantaran District, Probolinggo. In this case, the researcher used descriptive qualitative methods. Observation, interviews, and documentation were used in the data collection techniques and to analyze the data the researcher used data reduction, data presentation, and drawing conclusions techniques. This research showed that the emotional intelligence and religiosity of adolescents in Kramatagung village are categorized as poor, but parents in implementing parenting styles for children in Kramatagung village are quite democratic. Furthermore, based on research it is known that the emotional intelligence and reliability of adolescents in the Kramatagung village are quite an apprehension. The adolescents who are emotionally intelligent and have good religious intelligence are educated by applying democratic parenting. It is the duty of parents to educate, guide, nurture, and always remind also advise the children not to be trapped by world life which increasingly shows freedom in an association. Guidance and education especially in the family are top priorities in addition to other education outside the home.
\end{abstract}

Keywords: Democratic parenting, emotional intelligence, religiosity. 


\section{A. INTRODUCTION}

The young generation is the next nation's generation in today's life. A sense of patriotism must be embedded in the souls of the young generation. The generation of national fighters must have strong provisions especially in their leadership, noble character, creative power, patriotism, idealism, and must have a healthy soul both physically and spiritually. But nowadays, juvenile delinquency is increasing and varies every day. The current young generation is expected to be a substitute and have better quality than the previous generation. Juvenile delinquency is an interesting study to be examined because in this millennial era, hopefully, teenagers could be at the forefront of continuing the ideals of the nation's struggle, not becoming a destroyer for the nation's life. Adolescent delinquency is increasing, including fights between students, drinking alcohol, and drugs are very detrimental to oneself, family, and society. There must be a solution for every problem that occurs among these adolescents to reduce juvenile delinquency levels.

From the various juvenile delinquencies that often occur, such as skipping school, smoking, drinking alcohol, drugs, street motor racing, student fights, gang fights, and so on. Even today, both in rural areas and urban areas the news is still colored about delinquency. Based on data from the police, in a month every weekend, on average there are two incidents of a brawl between students. ${ }^{1}$ This juvenile delinquency can be caused as a result of low emotional intelligence in adolescents. Emotional intelligence as stated by Solehudin is smart someone or smart in controlling his emotions. $^{2}$

Emotional intelligence has been existed and owned by humans since they were born. This emotional intelligence grows and develops in every stage of a person's life. The theory of the development of emotional intelligence was put forward by Erikson, namely the Theory of PhysicalEmotional Development. According to Erikson the stages of emotion in

${ }^{1}$ MUSTIKA DWI AGUSTIN, "KECERDASAN EMOSIONAL REMAJA DI SMA NEGERI 3 PADANG TAHUN 2012 Penelitian Keperawatan Jiwa MUSTIKA DWI AGUSTIN" (2012).

2 Much Solehudin, "PERAN GURU PAI DALAM MENGEMBANGKAN KECERDASAN EMOSIONAL (EQ) DAN KECERDASAN SPIRITUAL (SQ) SISWA SMK KOMPUTAMA M 
humans include the ability to recognize one's own emotions, manage emotions, motivate oneself, recognize other people's emotions, and be able to build good relationships between humans. The stage of development can develop from birth to old age. In adolescence, emotional intelligence has a major role in reaching the achievement. Research conducted by Parker, J.D.A. regarding the relationship between emotional intelligence and academic strength in the educational field showed that emotional intelligence is very important. This is also supported by research conducted by Carso, S.M regarding the relationship between emotional intelligence and adolescent special abilities. ${ }^{3}$

Students who have good special abilities have a higher value for emotional intelligence than those who have fewer special abilities. This study also showed the influence of children's emotional intelligence on their social stages, where children who have higher emotional intelligence show a better social development stage compared to children who have low emotional intelligence. The family has the main and most important function for the formation of the child's personality. The family environment has a big influence and determines the child's personality. Family is the child's initial environment consciously or indirectly it will directly affect the child's education. ${ }^{4}$

Based on temporary observation on $5^{\text {th }}$ of January 2020 in Kramatagung Village at 11.30 PM `many children are less educated from their parents due to lack of communication, openness between families. Community is classified as very minimal who care about the developments of morality. When parents give pay less attention and do not care about children's activities, the children will act arbitrarily, children prefer to spend time gathering and playing with their friends. Many children prefer to join the older people in terms of age and who already have a teenage mindset. This can harm the development of children's intelligence and religiosity. This environment will make the children lazy, unruly, act on their own, and dare to fight against people who are older than their age.

\footnotetext{
${ }^{3}$ AGUSTIN, "KECERDASAN EMOSIONAL REMAJA DI SMA NEGERI 3 PADANG TAHUN 2012 Penelitian Keperawatan Jiwa MUSTIKA DWI AGUSTIN."

4 Tina Sari, "Dampak Kegiatan Jamaah Tabligh Terhadap Keharmonisan Keluarga Di Desa Celuak Kecamatan Simpangkatis” (2016).
} 
The reason why parents cannot monitor children's behavior is that many of them work so far or outside Java Island. Parents entrust their children to their grandparents so that their children don't want to be advised anymore and are lazy to obey the orders. The children prefer to hang out with their friends. Many parents in Kramatagung Village pay less attention to children's development because their children are no longer able to be advised. The children often fight their parents and some parents are even afraid of their children.

Subsequent observations on $27^{\text {th }}$ January 2020 in Kramatagung Village at 4.30 PM also occurred in several cases, namely that parents fully entrusted their children to their grandparents for various reasons such as working overseas, farming in the fields all day long, broken home families, and have many children. Therefore, entrusting children to their grandparents is an effective choice for parents in Kramatagung Village. Children spend more time effectively with grandparents than with their parents. The impact experienced by children is to become unfamiliar and difficult to have warm communication with parents. The bad influence of the surrounding environment also dominates the children's attitude. From the cases above, can be seen that parenting styles have an important role in children's development, especially children's emotional intelligence. Therefore, this study wants to know in-depth about the democratic parenting style of parents in building emotional intelligence and adolescent religiosity.

\section{B. RESEARCH METHOD}

This research used a qualitative descriptive approach. A qualitative descriptive approach is to understand the meaning of events related to subjects in the field to obtain the necessary data. ${ }^{5}$

The data collection techniques used were observation, interview manuscripts, field notes, photos, and other official documents. Direct observation of the object under investigation or get directions to the field

5 Widya Iswara, "Pendekatan, Jenis Dan Metode Penelitian Pendidikan," Direktorat Tenaga Kependidikan Direktorat Jenderal Peningkatan Mutu Pendidik Dan Tenaga Kependidikan Departemen Pendidikan Nasional (2008): 39. 
according to what is needed, ${ }^{6}$ to get the real data and to test the data that has been obtained by researchers. The criteria were as follows: Extended participation, diligent observation, triangulation. Data analysis techniques used data reduction, data presentation, and concluding. ${ }^{7}$

\section{DISCUSSION}

\section{Democratic Parenting in Building Adolescent Emotional Intelligence}

Democratic parenting is the parenting style of parents who apply treatment to children to shape the child's personality by prioritizing the interests of rational children. ${ }^{8}$ If it is good then it needs to be accustomed to and if it is not good it should not be done again. ${ }^{9}$ According to Hurlock (1996), democratic parenting style of the parents is the parenting style of the parents applying treatment to children to shape the child's personality by prioritizing the interests of rational children. ${ }^{10}$

Children tend to do things they see and hear because their thinking skills have not developed properly, so modeling is an important factor in the good and bad things of children in Kramatagung Village Bantarana Probolinggo. Democratic parenting is considered the most adequate to be applied to teenagers and other family members. This is because, in a democratic parenting system, the aspirations of each individual are well accommodated so that each individual is respected according to their capacities and capabilities. The democratic parenting system teaches

6 Hasyim Hasanah, "TEKNIK-TEKNIK OBSERVASI (Sebuah Alternatif Metode Pengumpulan Data Kualitatif Ilmu-Ilmu Sosial),” At-Taqaddum 8, no. 1 (2016): 21.

${ }^{7}$ Sri Adi Widodo dan A. A. Sujadi, "Analisis Kesalahan Mahasiswa Dalam Memecahkan Masalah Trigonometri," SOSIOHUMANIORA: Jurnal Ilmiah Ilmu Sosial dan Humaniora 1, no. 1 (2015): 51-63.

82017 Masni, "Peran Pola Asuh Demokratis Orangtua Terhadap Pengembangan Potensi Diri Dan Kreativitas Siswa," Jurnal Ilmiah Dikdaya 6, no. 1 (2017): 58-74.

${ }^{9}$ Agung Wahyuddin, "Pola Asuh Orang Tua Nelayan Dalam Membimbing Anak Di Desa Campurejo Kecamatan Panceng Kabupaten Gresik," Paradigma 02, no. 01 (2014): 1-9.

${ }^{10}$ DIANA SHOFIYATUL HASANAH, "HUBUNGAN ANTARA POLA ASUH DEMOKRATIS ORANG TUA DENGAN SIKAP KREATIF SISWA KELAS VIII DI MTsN GRESIK”(2012): 16. 
teenagers that the rights and obligations of each individual must be properly respected. ${ }^{11}$

Adolescence can be said to be a critical period, the transition phase from childhood to adulthood. Adolescence is the starting point for growing into an adult. Whether to be an emotionally mature adult and able to handle life's problems well, or to grow up to be a fragile and independent person. Adolescents as humans who are growing and developing continue to carry out social interactions both between adolescents and with other environments. Through the adaptation process, adolescents get recognition as members of a new group in their surrounding environment. Adolescents are also willing to adopt the habits that apply in a group of adolescents. ${ }^{12}$

Generally, emotional upheaval accompanies the changes that occur in adolescents, both physically and psychologically. In this phase, emotional intelligence is needed to be able to adjust as soon as possible to all these changes. Environmental influence begins with association with friends. At $12^{\text {th }} 15^{\text {th }}$ years old, friendship is a close relationship that is bound by common interests, mutual interests, and sharing feelings, helping each other to solve problems together. Peers are a group of people with the same age level and have relatively the same feelings and pleasures. ${ }^{13}$

The example given by parents as the role model in the RT $028 \mathrm{RW}$ 007 environment is very less because many parents do not pay attention to the behavior that the child will see and imitate also with the bad words of the parents so that many children always say the word which is not good as well as exemplary in the aspect of worship, many parents rarely invite their children to pray and recite the Holy Qur'an together and allow their children to always play and there are even some parents who rarely pray or read the

${ }^{11}$ HISBIYATUL FIKRIYAH, "PENGARUH POLA ASUH DEMOKRATIS ORANG TUA TERHADAP PRESTASI BELAJAR PENDIDIKAN AGAMA ISLAM SISWA KELAS VII DI SMP KYAI HASYIM TENGGILIS SURABAYA," Revista Brasileira de Ergonomia 9, no. 2 (2016): 10.

12 Pramudyasari Nur Bintari and Cecep Darmawan, "Peran Pemuda Sebagai Penerus Tradisi Sambatan Dalam Rangka Pembentukan Karakter Gotong Royong," Jurnal Pendidikan Ilmu Sosial 25, no. 1 (2016): 57.

13 Silfia Rahmah, Asmidir Asmidir, and Nurfahanah Nurfahanah, "MasalahMasalah Yang Dialami Anak Panti Asuhan Dalam Penyesuaian Diri Dengan Lingkungan," Konselor 3, no. 3 (2014): 107. 
holy Qur'an. Several parents or family as caregivers agreed based on the results of the interview:

"jujur, peran orang tua sangat penting dan besar pengaruhnya untuk anak agar ia menjadi anak yang masa perkembangan tumbuh dengan optimal.".

"kecerdasan emosi bagi anak saya memang penting, apalagi ketika berbaur dengan orang yang lebih tua". (bg)

"Peran orang tua emang peting tentang mengontrol kecerdasan emosional anak, apalagi anak saya yang sering kluar sama tmennya, maen handphone sehingga lupa akan kewajibannya yaitu sholat, ngaji dll.". (bp)

"kecerdasan emosional sangat penting bagi anaknya, terutama saya sebagai orang tua harus bisa mengontrol emosi anak saya, sehingga anak saya tidak cepat emosional". (il)

"kecerdasan emosional memang penting bagi cucu saya, tapi karna orang tuanya yang merantau, sifat dan tingkah lakunya kurang terkontrol, saya yang sudah tua tidak cukup untuk membina tentang kecerdasan emosional tersebut,". (mr)

"seperti yang mas katakan kecerdasan emosional sangat penting bagi anak, tapi seiringnya waktu, сисu saya kurangnya perhatian dan kasih saying dari orang tuanya, karna orang tuanya merantau, jadi emosional pada сиси saya jadi terganggu, akibatnya sering kluar malem”. (mri)

"bagi saya ya mas, kecerdasan emosional itu sangat penting bagi anak, saya sebagai orang tua amat harus bisa membantu mengontrol emosi anak saya, apalagi sekarang anak saya jarang di rumah pulang kerja bukannya tidur malah langsung keluar lagi, jadi saya sebagai orang tua kurang tegas, mungkin dengan sharing antar ayah dan anak akan membantu kecerdasan emosional anak saya". (ma)

The researchers concluded that parents understand the importance of emotional intelligence for children. The parents' foster care only understands but in practice it only communicates questions and answers about daily activities.

In Kramatagung Village, the teenagers committed many irregularities, for example, disobeying their grandfather about the rules set 
in the family, because of a lack of supervision from parents and many parents have migrated outside Java.

\section{Democratic Parenting in Building Youth Religiosity}

Parents have the most important role in the family in human life, especially in terms of shaping the character of children. In their daily life, the parenting style of parents is very determining the child's growth and development because children will immediately accept and record what they get from their parents and what they receive will be applied in everyday life so that the democratic parenting of parents determines their behavior in life. The family as an initial transformation process for children's education has an important role as the nation's next-generation and their quality in society. The family is the cultivator of noble values (akhlakul Karimah) because the family is an example or role model for other family members and parents are the main role models in the family environment. ${ }^{14}$

The democratic parenting style of parents which is religiosity is the parenting pattern given by the parents as a provision in life. Education is very important, especially religious education that must be instilled for children and taught in life especially in this millennial era which currently has a lot of influence from many aspects of life. Humans have an instinct called a religious instinct, which is to believe in worshiping a force outside to the human. This religious instinct is what drives people to be religious. This religious aspect cannot be separated from life. ${ }^{15}$

Every parent wants their children to live in kindness and not in aberration as is often the case in the current millennial era, for the way parents instill diversity from an early age to their sons and daughters, as revealed by one of the informants:

"agama sangat penting dalam kehidupan apalagi agama sebagai pengendali mas bagi perilaku keseharian saya dan keluarga. apalagi untuk anak saya, sejak kecil saya mengajarkan kepada anak-anak untuk

${ }^{14}$ Wusono Indarto, "Peranan Keluarga Dalam Mempersiapkan Kemandirian Anak Untuk Menghadapi Masalah-Masalah Dalam Kehidupan" (2015): 115-119.

15 Alrieza Mufajri Sasmitho, "HUBUNGAN ANTARA RELIGIUSITAS DENGAN KONSEP DIRI MAHASISWA PROGRAM STUDI BIMBINGAN DAN KONSELING UNIVERSITAS NEGERI YOGYAKARTA ANGKATAN 2010,” no. September (2013). 
berperilaku baik dan sesuai dengan ajaran agama. agar nantinya anak saya dapat memahami dan mengerti serta membiasakan perbuatan baik dan tidak menyimpang dari agama dan tidak terjerumus ke hal yang bersifat negatif". (bg)

Parents generally always give and want to get the best for their offspring as the successor and pride of the parents as expressed by the informant.

"saya dalam mendidik anak tidak selalu menginginkan apa yang saya ingikan akan tetapi hanya mengarahkan mana yang terbaik bagi anakanaknya, tetapi saya selalu menanamkan mengingatkan dan menyarankan hal baik yang sesuai dengan kemampuannya mas. sehingga tanpa saya awasi anak saya tentu akan dapat membedakan perbuatan baik dan buruk, sesuai dengan ajaran agama dan akan menjauhi hal-hal yang dilarang oleh agama". (bt)

As a farmer, Mrs. Lilik also said that to instill kindness in children of course starts from the style of parenting and educating religion from childhood.

"perilaku beragama sangat penting mas dalam kehidupan, apalagi sebagai makhluk yang saling membutuhkan pada makhluk hidup lainnya, saya dan keluarga selalu membiasakan hal-hal yang tidak menyimpang dari agama dan kelak anak -anak saya dapat menjadi panutan bagi orang lain dan masyarakat sekitarnya".

Another reason was stated by Mbah Rokhim that: "pendapat saya mas...sikap dan kebiasaan yang saya ajarkan pada keluarga saya agar anak keturunan saya itu berbuat baik dan tidak melanggar norma yang ada dalam masyarakat apalagi menyimpang dari ajaran agama sehingga menjadi oirang yang bermanfaat bagi orang lain dan masyarakat sekitar.

"cara yang saya gunakan dalam menumbuhkan perilaku religiusitas pada keluarga dan cucu saya, biasanya saya menyarankan dia bergaul dengan teman-teman yang baik dan jangan bergaul dengan teman yang kurang baik karena dapat mempengaruhi perilakunya, mengikuti organisasi keagamaan, dengan begitu сиси saya akan cepat mengerti pentingnya menerapkan perilaku beragama dan pembiasaan dan contoh dirumah juga sangat menunjang.

Mbah Rizal also stated that: 
"menurut saya, dalam mengajarkan kepada cucu saya adat kesopanan sebagai orang timur dimanapun dia berada, menghormati yang lebih tua dan menyanyangi yang muda, menghargai orang lain, sehingga cucu saya dihormati dan dihargai orang lain dan masyarakat dimanapun dia berada".

Menurut wawancara dengan mbah andi "mbah selalu berusaha menyuruhnya mengaji, ke tempat pengajian, sekolah madrasah agar cucuku dapat ilmu agama dan dapat menerima nasehat."

\section{The Role of Parents and Their Barriers in Building Emotional Intelligence and Youth Religiosity}

The role of parents in terms of life greatly determines the behavior and thinking patterns of children in various ways. The parenting style that parents apply in their daily lives is also very influential on children, especially in the familiarization that is carried out in the family which will certainly affect the child's behavior until grow up. If in that family the orientation of religious behavior is good of course the orientation is very strong, while if the parents are far from religion, of course, the child will also be far from religion although not everything is like said above, in reality, the habituation and parental example will determine the child's behavior.

Parents who apply democratic parenting will make children able to appreciate and accept criticism and advice from others, be responsible in their lives, have a strong level of self-confidence, and can respect others. Parents in implementing parenting styles in their families will apply various kinds of parenting styles. This will be done so that the parenting styles that are applied can have a good effect on their children. In the application of parenting, parents do not apply one kind of parenting but choose mostly to combine parenting styles that are suitable in their families.

The obstacles that occur to a person will be able to influence and affect each individual himself and also the environment in which he lives, so the obstacles that occur in building emotional intelligence and children's religiosity are two factors, namely the individual itself and the environment. Barriers come from individuals or parents themselves if parents do not pay attention to children. They are only busy with work outside the city so that the lack of time with their children is a major obstacle. Usually, parents entrust Islamic institutions in sending their children to become more 
superior individuals. This is very helpful for parents in shaping and instilling noble behavior for children.

The factors of a disharmonious family are also one of the causes, lack of communication or breakdowns in communication from father and mother. Lack of communication between father and mother is the impact of a disharmonious family, both of them do not know what to expect in a family and both of them are only busy with their activities and have no time with family. From this lack of communication to a lack of mutual respect, mutual love between family members, and a lack of mutual help so that they tend to act individually in the family.

Another factor is emotion, which dominantly affects individual behavior. Emotion refers to certain feelings and thoughts which are physical and mental states and have a tendency to do something. Emotion is an impulse to do something. ${ }^{16}$

Emotions that occur in a person do not always show negative behavior, but also show positive behavior. Emotions provide a variety of nuances and atmospheres in one's life journey and how a person controls emotions.

Parents in applying democratic parenting to build children's emotional intelligence and religiosity are a process to deal with changing times which from time to time will increase in sophistication. Lifestyles that have been heavily influenced by circumstances and the shows that are served in various media, so that parents will have to be able to filter influence from that enters to the children to adult's life based on their respective religious rails so that parents understand how to educate children at home and outside the home with various kinds of appropriate parenting styles so that they can keep up with the times.

How parents educate their children to vary from a family to another family. A child will be able to receive examples and habits from parents about attitudes and religious behavior if the application is consistent in the family. Fauzi, 2017 said that:

1. A set of rules in directing the rules in society.

2. The concept that must be carried out by individuals and society

\begin{tabular}{lcc}
\hline${ }^{16}$ Yulia & Suriyanti, “" & EMOTIONAL LEARNING " \\
PENGEMBANGAN PENDIDIKAN KARAKTER,” no. November (2015). & \\
\hline
\end{tabular}

Democratic Parenting in Developing Emotional Intelligence and Youth Religiosity... 
3. Individual behavior is an important part of society. ${ }^{17}$

The family is an institution that has the following functions:

1. Arranging an intimate relationship between husband and wife

2. Development of offspring by the rules that have been agreed upon together in the family

3. Introducing new members of the community by the expectations of the family and society.

4. Families give and develop a love for their children

5. Family gives status in society

6. Protect family members. ${ }^{18}$

Family plays an important role in giving expectations to a child, especially teenagers who are vulnerable to get external and internal influences. The application of parenting in building religious children is influenced by the conditions of the family and the environment as well as the individual.

The role of these parents will certainly make their children have a good attitude and always obey the rules from God and parents, devoted to their parents, and have a strong religion so that children can filter external influences that come to them. So that religious law and rules can be applied in society.

Among the strategies used by parents in building children's emotional intelligence and religiosity, one of them is by actively participating and inviting them to religious activities, for example, the yellow book recitation, recitation of youth mosques, general recitation, joining religious organizations both in groups and the general public. It is intended to get physical and spiritual provisions in social life and daily life.

Through the socialization process of the family, the roles of the parents are appropriate. This education in the family is expected for a child to become the child that follows the norms in society based on religion wherever they are.

The obstacles faced by some parents in Kramatagung village in implementing democratic parenting in building children's intelligence and

\footnotetext{
${ }^{17}$ Muhamad Rais Fauzi, PERANAN ORANG TUA DALAM SOSIALISASI NILAINILAI KEAGAMAAN TERHADAP ANAK DI DALAM KELUARGA, 2017.

${ }^{18}$ Suarga, "ISLAM DAN LINGKUNGAN SOSIAL" V, no. 3 (2016): 141-149.
} 
religiosity are because many parents work outside the city and region, some become migrant workers so that supervision and the examples given are difficult. It is well realized because it is not face-to-face and does not communicate every day so that children are ineffective and tend to underestimate what their parents give and difficult to receive advice and religious education from parents. Children are more likely to listen to people they meet every day in the family, for example, their grandparents and other families. Even though what they teach is deviant they will still obey it because they are there when they need it. Some are more inclined to invite their friends even though it is not the same as the rules in the family and society. That is why many of them follow into deviant behavior such as drinking, gambling, adultery, and so on.

These constraints are one of the causes which parents convey is difficult for children to accept democratic parenting in building emotional intelligence and religiosity. Moreover, the low level of parental education (elementary school graduate) also affects the mindset of children and also the mindset of parents about education. There are few high levels of education but have not succeeded in work or the economy is still mediocre and there are few people whose education is low but the economy is successful for their families. In this day sometimes success is only seen by how many possessions you have until forget that an invaluable treasure is a child who has a high level of emotional intelligence and religiosity or a child with noble character.

\section{CONCLUSION}

Parenting is very influential in everyday life, so the participation of parents is needed in supervising the education of their sons and daughters to make them become pious and good children based on the expectations of their parents, especially in building emotional intelligence and children's religiosity. this is the foundation for children to continue their lives for their future.

In RT.028 RW.007 Kramatagung Village Bantaran Probolinggo based on the results of research that parents in Kramatagung village still do not meet the minimum criteria in building children's emotional intelligence and religiosity and must be improved again in giving guidance, paying attention to children and discipline to their children in providing religious 
education. Parents have not fully controlled their children so that they underestimate what has become Islamic law and the development of children's intelligence and religiosity is difficult to achieve, while supervision and parental exemplary in everyday life is not maximal at their activities and many both internal and external influences have not fulfilled what most parents expect. In general, parents especially in Kramatagung village are quite busy with their work and their respective activities. Whereas every parent has their way of applying in providing education to their children, but their goal is to make their children pious and of course every parent hopes that their children have good emotional intelligence and also high religiosity so that they can become good children but the efforts made by parents in the village of Kramatagung are still not maximal.

The role of parents in everyday life becomes a stepping stone for children to have a good attitude. Therefore parents have an important and main role to educate their children both in family and social life, especially in this modern era when it is very sophisticated to deal with the changes in many aspects is needed. Active roles in emotional intelligence and religious levels of children are needed wherever they are because the attention and affection and supervision of parents make children more focused on facing the modern era. In today's era, many things happen in society, many incidents raise a person's privacy but it is no longer the privacy of an individual but is commonly exposed in the community.

Parents should provide the best love, attention, education, and supervision for their children so that they are not affected and fall into the freedom of this modern era. The attention and upbringing of the family especially parents, greatly determine the character of the child because education in the family also affects the development of the child both in his family and in the surrounding community. A child will be able to develop as expected if the education in his family is good. If the education that is taught is not good or the parents do not provide an example or role model which according to the child is not good, of course, it will greatly affect the child. So that even though the children are sent to school in their favorite institution, the results will not be optimal. The role of parents is very much needed in facing the modern era because it will be a provision for social life. 


\section{BIBLIOGRAPHY}

AGUSTIN, MUSTIKA DWI. "KECERDASAN EMOSIONAL REMAJA DI SMA NEGERI 3 PADANG TAHUN 2012 Penelitian Keperawatan Jiwa MUSTIKA DWI AGUSTIN" (2012).

Fauzi, Muhamad Rais. PERANAN ORANG TUA DALAM SOSIALISASI NILAI-NILAI KEAGAMAAN TERHADAP ANAK DI DALAM KELUARGA, 2017.

FIKRIYAH, HISBIYATUL. "PENGARUH POLA ASUH DEMOKRATIS ORANG TUA TERHADAP PRESTASI BELAJAR PENDIDIKAN AGAMA ISLAM SISWA KELAS VII DI SMP KYAI HASYIM TENGGILIS SURABAYA.” Revista Brasileira de Ergonomia 9, no. 2 (2016): 10.

HASANAH, DIANA SHOFIYATUL. "HUBUNGAN ANTARA POLA ASUH DEMOKRATIS ORANG TUA DENGAN SIKAP KREATIF SISWA KELAS VIII DI MTsN GRESIK" (2012): 16.

Hasanah, Hasyim. "TEKNIK-TEKNIK OBSERVASI (Sebuah Alternatif Metode Pengumpulan Data Kualitatif Ilmu-Ilmu Sosial).” AtTaqaddum 8, no. 1 (2016): 21.

Indarto, Wusono. "Peranan Keluarga Dalam Mempersiapkan Kemandirian Anak Untuk Menghadapi Masalah-Masalah Dalam Kehidupan" (2015): 115-119.

Iswara, Widya. "Pendekatan, Jenis Dan Metode Penelitian Pendidikan."

Direktorat Tenaga Kependidikan Direktorat Jenderal Peningkatan Mutu Pendidik Dan Tenaga Kependidikan Departemen Pendidikan Nasional (2008): 39.

Junaidi, Junaidi. "Model Pendidikan Multikultural." Al-Insyiroh: Jurnal Studi Keislaman 2.1 (2018): 57-72.

Masni, 2017. "Peran Pola Asuh Demokratis Orangtua Terhadap Pengembangan Potensi Diri Dan Kreativitas Siswa." Jurnal Ilmiah Dikdaya 6, no. 1 (2017): 58-74.

Nur Bintari, Pramudyasari, and Cecep Darmawan. "Peran Pemuda Sebagai Penerus Tradisi Sambatan Dalam Rangka Pembentukan Karakter Gotong Royong.” Jurnal Pendidikan Ilmu Sosial 25, no. 1 (2016): 57. Rahmah, Silfia, Asmidir Asmidir, and Nurfahanah Nurfahanah. "Masalah-

Masalah Yang Dialami Anak Panti Asuhan Dalam Penyesuaian Diri Dengan Lingkungan.” Konselor 3, no. 3 (2014): 107. 
Ramdhan, Tri Wahyudi. "Dimensi Moderasi Islam." Al-Insyiroh: Jurnal Studi Keislaman 2.2 (2018): 29-48.

Ramdhan, Tri Wahyudin. "Model Pengembangan Kurikulum Multikultural." Al-Insyiroh: Jurnal Studi Keislaman 5.2 (2019): 3953.

Sari, Tina. "Dampak Kegiatan Jamaah Tabligh Terhadap Keharmonisan

Keluarga Di Desa Celuak Kecamatan Simpangkatis" (2016).

Sasmitho, Alrieza Mufajri. "HUBUNGAN ANTARA RELIGIUSITAS DENGAN KONSEP DIRI MAHASISWA PROGRAM STUDI BIMBINGAN DAN KONSELING UNIVERSITAS NEGERI YOGYAKARTA ANGKATAN 2010," no. September (2013).

Solehudin, Much. "PERAN GURU PAI DALAM MENGEMBANGKAN KECERDASAN EMOSIONAL (EQ) DAN KECERDASAN SPIRITUAL (SQ) SISWA SMK KOMPUTAMA MAJENANG” 1 (2018): 43.

Suarga. "ISLAM DAN LINGKUNGAN SOSIAL" V, no. 3 (2016): 141149.

Sujadi, Sri Adi Widodo dan A. A. "Analisis Kesalahan Mahasiswa Dalam Memecahkan Masalah Trigonometri." SOSIOHUMANIORA: Jurnal

Ilmiah Ilmu Sosial dan Humaniora 1, no. 1 (2015): 51-63.

Suriyanti, Yulia. "" EMOTIONAL LEARNING " SEBAGAI PENGEMBANGAN PENDIDIKAN KARAKTER," no. November (2015).

Wahyuddin, Agung. "Pola Asuh Orang Tua Nelayan Dalam Membimbing Anak Di Desa Campurejo Kecamatan Panceng Kabupaten Gresik." Paradigma 02, no. 01 (2014): 1-9. 